\title{
Commercial Media, the Military, and Society in Turkey during Failed and Successful Interventions
}

\section{F. Michael Wuthrich}

To cite this article: F. Michael Wuthrich (2010) Commercial Media, the Military, and Society in Turkey during Failed and Successful Interventions, Turkish Studies, 11:2, 217-234, DOI: 10.1080/14683849.2010.483860

To link to this article: http://dx.doi.org/10.1080/14683849.2010.483860

曲 Published online: 29 Sep 2010.

Submit your article to this journal $\pi$

Llll Article views: 314

Q View related articles ¿

Citing articles: 4 View citing articles $\square$ 


\title{
Commercial Media, the Military, and Society in Turkey during Failed and Successful Interventions
}

\author{
F. MICHAEL WUTHRICH \\ Department of Political Science, Bilkent University, Ankara, Turkey
}

\begin{abstract}
As widely observed by scholars, a marked change in the interaction between military and society in Turkey took place during the 1997 February 28 Process, which differed drastically from the military's behavior toward society during earlier interventions and attempts from 1960 to 1980. A prime factor in this change seems to be the advent of commercial media, leading to important changes in information control, greater oversight from society on the actions of state and military elites, and the internalization of consumerism among Turkish citizens, the results of which extend even to the foundational assumptions underlying the Ergenekon indictments, which address allegedly subversive activities spanning from 2003 to 2008.
\end{abstract}

Former president (and prime minister on multiple occasions) Süleyman Demirel has been attributed with saying that "God first created the Turkish army, then he realized he had forgotten something and added the people as an afterthought." ${ }^{1}$ The quip, offered by the seasoned politician shortly after he was ousted from his premiership in the 1980 coup, points to the traditional dominance the military has had within the Turkish polity. Though exaggerated sentiment, if one examines the nature of the Turkish polity as an arena filled with various actors, since the passing of the hero and founder of the Republic, Mustafa Kemal Atatürk, the military makes a persuasive case for being the most dominant. During the earlier times of crisis in 1960, 1971, and 1980, they directly intervened in the political sphere under the auspices of restoring order and protecting the founding principles of the Turkish Republic. In each case and within a relatively short amount of time they returned to their barracks and reinstalled civilians to power. ${ }^{2}$ In addition to these events, prior to 1971 there were also a number of instances in which juntas (led by junior officers) attempted to appropriate the reins of power but ultimately failed.

In each of these earlier attempts, whether failed or successful, though the actions were instigated by conditions ultimately existing within society at large, the significant actors within the "arena of intervention" were understood as the military and

Correspondence Address: F. Michael Wuthrich, Department of Political Science, Bilkent University, Bilkent, Ankara 06800, Turkey. Email: wuthrich@bilkent.edu.tr. 
political elites. Society as a whole seemed to be understood as a spectator, observing the spectacle from the sidelines. In the course of events, the public seemed to be perceived as an "afterthought" - not insignificant in meaning and existence but in the context of being an active agent involved in the event. As Metin Heper points out, the military always showed concern for legitimizing their decision to intervene to the society at large, ${ }^{3}$ but legitimacy was primarily provided (usually to a receptive public) post hoc. In other words, non-political elite society was not understood as a potential actor in the events; instead, the military consistently behaved in a pattern that seemed to reflect an understanding of society as a spectator that could be convinced by legitimization and the tools of control at their disposal following the intervention.

By spring 1997, however, the rules and the understanding of the arena and the actors within it had changed. When the Refahyol government, a coalition government combining the center-right True Path Party (Doğru Yol Partisi, DYP) and the Welfare Party (Refah Partisi, RP), was finally pushed from power, the effective thrust consisted of an organic construction of the military and various sectors of civil society working in tandem. It suddenly appeared that the military found it necessary to utilize "society as actor" to gain legitimacy and to assist in the realization of their goals. A perusal of more recent events seems to show that this new, more interactive role for non-political elite civilian elements has become an accepted necessity. For instance, even the assumptions underlying the Ergenekon indictments, in which retired and active military personnel along with elements from the media and civil society have been accused of plotting to intervene to oust the Justice and Development Party (Adalet ve Kalkınma Partisi, AKP) from power, help to further this claim.

While scholars of Turkish politics and civil-military relations have addressed the observation of this clear change of interaction in different ways, the focus seems to have been on observing the transformation rather than explaining it. Nil Satana, for example, argues that, beginning from 1990, the Turkish Armed Forces (TAF) are transforming into a "postmodern military" but does not clarify what it was that could have brought about such a distinct attitudinal change. ${ }^{4}$ Haldun Gülalp asserts that the military's behavior during the February 28 Process "befits the postmodern times." ${ }^{, 5}$ Such examples, and there are many others, give evidence of a change, but a mere relegating of the enormous and quickly-altering structural changes to the world of "postmodernism" seems inadequate. There is no consensus on the actual substance of "postmodernism"-is it an attitude, a way of life, a system of social structures, a description, an active agent? —and, in any case, there must be factors underlying its genesis.

What could account for the distinct "postmodern" change between the coup of September 12, 1980, and the February 28 process in 1997? In fact, if one turns to the legal foundations or constitutionally-mandated institutions for a possible resolution to this question, the problem is exacerbated. The 1982 Constitution, constructed by the military regime after the 1980 coup, gave the military broader powers through the National Security Council (Milli Güvenlik Kurulu, MGK) and curbed the rights 
of individuals and civil society in comparison to the 1961 Constitution. Though some aspects of the curbing of rights and the increased powers of the MGK have been subsequently amended, most of these changes occurred after the events of 1997; therefore, such changes do not explain the timing of the altered interaction of the military with society, nor does the curbing of civil society's rights seem to logically correspond to a more mobilized and active civil society.

This article argues that a significant factor contributing to the change in approach of the military toward society can be traced to the introduction of commercial (i.e. private) media in Turkey - the product and effective agent of consumerism-and the subsequent structural changes it brought to society, forcing the TAF to adjust how it related to society, particularly apparent in times of crisis and intervention. When media broadcasting to the Turkish masses went from being state-controlled and monolithic to privately run and pluralistic, it transitioned from a tool of the state or military (when necessary) to inform and convey to a contested arena in which they became one voice that had to compete with others for social consent. Its advent also became a prime catalyst for a new type of citizen, one that was increasingly aware of her/his role as consumer-one who is provided with and actively makes choices and takes ownership of various objects. This change facilitated a need for a new approach in the pattern of interaction between the military and citizen consumers, necessitating, in times of perceived crisis, a courting of society and civil groups in order to both legitimate the "crisis" and elicit assistance or approval to intervene.

To this end, the emergence of commercial media (particularly television) in Turkey and the changes it wrought-especially to the understanding, scope, and "agents" of intervention-will be discussed below. In presenting this argument, the article does not intend to completely discount other important factors that also may have influenced this trajectory in civil-military relations. Economics, for example, has not had an insignificant effect on the relations between the TAF and society as a whole, especially since 1980. According to some scholars, the founding of OYAK (Ordu Yardımlaşma Kurumu, Armed Forces Mutual Assistance Fund) in 1961, an investment fund that was established to help the military independently provide for its retired soldiers, ${ }^{6}$ has come to play an increasingly important role in civil-military relations as the fund has grown. Linda Michaud-Emin argues that OYAK is one of the military's significant "unofficial means of influence" because of its size, special benefits, and impressive portfolio. However, what she has failed to recognize is that such forms of financial power can also be a significantly constraining force as the power that is acquired through markets is also dependent on those markets; thus, the perceptions and whims of others, both national and transnational, have an increasingly potent effect on one's fortunes, leading to greater constraint in one's actions rather than greater flexibility.

Therefore, while it might be argued to have a moderating effect on the intensity of interventions, it would not necessarily affect the interaction structure of the interventions that have taken place. A quick review of the financial history of OYAK unearths further incongruence in this argument. William Hale notes that in 1972 OYAK as a holding had assets hovering around $\$ 300$ million, which, "in a country 
where the commercial capital market was in its infancy" ${ }^{\prime 8}$ demonstrates a significant amount of relative economic power even at such an early date. In other words, if economic factors alone were enough to change the structure of military-society relations in times of perceived crisis, these features should have been observable in 1971 and certainly in 1980. In reality, however, though there seems to be an awareness of economic factors in all the coup attempts, the pattern of interaction between soldiers and civilians did not noticeably change with OYAK's growth. Therefore, though it might have made the military increasingly reluctant to intervene, when they did choose to intervene it did not seem to change the pattern of interaction.

Even if one maintains that economic considerations wrought changes not immediately obvious in terms of behavioral change, the critical changes introduced by commercialized media most likely heightened those considerations determining the behavior of the military in relation to society as a whole. The continued rise of the economy as a potent factor itself is potentially based on technological advances in mass communication and media and their increasing availability and accessibility to wider and wider audiences. In other words, the constraints in behavior that might come into play as one's economic portfolio grows would realize their potency in the context of a ubiquitous and commercialized media. Such media, and in particular commercial television, as it is the most widespread in usage throughout the country and therefore a primary manifestation of this reality, will be the object of emphasis throughout.

Furthermore, that commercial television would alter the relationship between the military and society is not an observation unique to the Turkish context. Udi Lebel also argues that privatization of the media (also in the early 1990s) in Israel led to the growth of civil society movements against the Israeli military. Prior to the commercialization of the media, military sovereignty greatly constrained the development of civil society. With the emergence of private media, Lebel claims that new environment opened the door for military confrontation with the new social movements over defense policy. ${ }^{9}$ Later, he states, private television's "reports about questionable military operations and failures revised the relationship pattern between the media and the defense arena." 10 Although the Israeli military's ability and strategy in dealing with the "revision" of their relationship with society has been different, it points out the significant impact of the introduction of commercial media within another context, further supporting that the consideration of its potential structural changes in Turkey is merited.

\section{The Advent of Commercial Television}

In the 1970s, a small, subtle, yet drastic revolution was occurring in the heart of Turkish society with the advent of television. As far as the dissemination of information is concerned, starting in at least the mid-nineteenth century, ${ }^{11}$ national and global events were selected and disseminated to the public through the medium of newspapers in the Ottoman Empire. Although these publications, to the extent possible, presented various viewpoints and perspectives, they nonetheless had an 
impact on a very narrow audience-mostly bureaucrats - and had very minor transformative power on the vast majority of society. Starting in the 1930s, with the initiation of radio broadcasting as a state-run enterprise, ${ }^{12}$ the door was open to reach an ever-wider Turkish audience. As the radio was state-controlled and mandated to "define and promote a common and collective agenda for modernization," 13 this form of media acted to reinforce unified understandings and experiences across the nation that could easily be formed and manipulated by those transmitting the messages.

In the 1970s, an entirely new fascination was generated at the arrival of television in Turkey to such an extent that it began to change cultural practices. Ersin Kalaycıŏlu writes:

The entire gamut of social interactions between families changed for a while in the early 1970s. Those who owned the new status symbols suddenly discovered that they, or rather their TV sets, constituted a great attraction. Relatives, friends, and neighbors, who they had not had very close interactions, suddenly rushed to take their seats in front of the TV sets. ${ }^{14}$

This drastic change in social norms, although observable on a smaller scale with radio in the $1960 \mathrm{~s},{ }^{15}$ represented a force much more potent as a catalyst for change due to its greater social desirability. In other words, although newspapers offered a much earlier opportunity for varying viewpoints to be communicated, people did not rush to their neighbors' or long-lost relatives' houses in the evening to read or have the newspaper read to them.

Sheer numbers help to emphasize this point. Whereas newspapers offer a total circulation of a few million (3.5 to 4), there were 7.2 million TV sets in operation in Turkey as early as $1987,{ }^{16}$ with those numbers continually growing. A national consumption survey in 1991 found that 60 percent of Turkish households owned color televisions. By 1993, there was 90 percent ownership of color televisions in Istanbul. ${ }^{17}$ The 1993 survey showed that 67.6 percent of adults $(79.7$ percent of women) never read the newspaper. ${ }^{18}$ As the significant impact of television could be widely seen, the advertising share also adjusted to reflect these realities. ${ }^{19}$ These drastic changes in the media and the enthusiasm it generated among the public occurred exactly during the period that societal-military relations started to change.

The initial enthusiasm generated by the entrance of television to Turkish society occurred under strict state control. Television and radio were administered through the Turkish Television and Radio Authority (TRT). Although it provided various forms of officially sanctioned programming, it also functioned as a centralized force for "the creation of national unity, through homogenized official Turkish language, national folkloric music, a shared sense of historic occasion, and loyalty to the nation." 20 Those millions tuning into this new technological development would receive the same news, transmitted to them with the same understanding, packaged neatly within the ideology sanctioned by the state. Although TRT was officially a state organ autonomous from party politics as stipulated in the 1961 Constitution, ${ }^{21}$ 
it was never autonomous from close supervision from above, and after the 1980 coup, with the establishment of the Supreme Board of Radio and Television (Radyo ve Televizyon Üst Kurulu, RTÜK) in $1983,{ }^{22}$ state-controlled media was even more carefully monitored by military oversight. Military representatives were appointed to RTÜK along with members of parliament to control and oversee broadcasting in Turkey. ${ }^{23}$

By the late 1980s and early 1990s, the ability to monopolize control of the airwaves turned out to be more difficult than anticipated. Starting with the broadcast from Germany of the privately run Star, unauthorized private stations began broadcasting into Turkey from neighboring countries. ${ }^{24}$ Seeing the success of the pioneering examples, others followed suit, rapidly increasing the numbers of channels available to the Turkish public. ${ }^{25}$ Not only that, these privately run stations were broadcasting with no oversight by the state. When the government decided to act to prevent the uncontrolled influx of stations, the people's thirst for the greater range of selection on the airwaves brought state and society into collision. Binnaz Toprak writes: "The decision met with millions of protestors who took to the streets, honking their automobile horns, demanding 'their' television and radio channels back on the air, a movement of protest that finally led to a change in the constitution."26

The political conditions in which the Constitution was amended to allow private television and radio further emphasize its profound importance in society. As noted by Özbudun, the governing coalition had put together a list of 13 constitutional articles on which there was mutual agreement regarding amendment, but the death of President Özal, the parliamentary election process of President Demirel, and the 1994 local elections caused the discussions of amending the Constitution to be temporarily shelved. Only one of these articles was passed in 1993 and accorded "special urgency." So while articles entailing the restrictions of fundamental rights and liberties (13), freedom of expression (26), freedom of the press (28), freedom of assembly (34), and others were held back from discussion until 1995, Article 133regarding television and radio broadcasts-was rushed through the amendment process with "special urgency." 27

How much did this really change? Why would this lead to a significant adjustment in civil-military interaction? Especially if the military representation on the board of RTÜK overseeing the programming of all channels broadcasting in Turkey until 2004 is taken into consideration, ${ }^{28}$ why would the existence of new commercial television stations make a critical difference? First, commercialized media decentralized the information source. Information was fractionalized and could no longer be communicated easily in a uniform way across society. Second, although control and oversight could be maintained, it could no longer be done so absolutely or discreetly. In other words, once numerous stations were broadcasting incessantly, it produced the nearly inevitable situation of oversight of the overseers. Finally, and perhaps most importantly, the vast variety (both in content and ideology) of information transmitted produced a situation where citizens were suddenly and consistently empowered to make choices and take ownership of the information they choose to receive in the complete privacy of their own homes. Society, increasingly 
aware of itself as a consumer, led to power-seeking actors realizing that they must "market" their perspective and agenda in order to gain consent.

\section{The Effect of Fractionalization and Oversight}

With commercial media the centralized and shared nature of information provided from a monolithic source was lost; therefore, the previous ability to easily control public understanding of "reality" and through this effectively control the public during times of intervention was no longer possible. The power of a controlled and centralized media source was observed immediately by the military with the first intervention of 1960. Nuran Y1ld1z writes that one of the first determinations after the May 27 coup was to improve and develop the working principles of the radio. ${ }^{29}$ Satana also writes that after this first intervention the radio was "heavily censured and manipulated" by the military. ${ }^{30}$ This control over a widely spread centralized force was particularly effective during periods of successful and attempted interventions.

The failed attempt to take over the government by former Colonel Talat Aydemir on May 21, 1963, helps to illustrate the power of a centralized media source during an intervention. With only a few tank battalions and the students at the Military Academy under his command, Aydemir seemed to have placed a great deal of the bravado for his intervention on controlling the Ankara radio station. To achieve this end, he dispatched a few tank crews, who managed to storm the entrance of the radio station in Ankara before transmission was cut for the night. The night reporter, frightened beyond usefulness to broadcast a stern message, left the announcement in the hands of First Lieutenant İlhan Baş:

Attention ... You will now listen to an announcement from the Turkish Armed Forces Intervention Central Headquarters ... Great Turkish Nation ... the Turkish Armed Forces have been obliged to take control ... The National Assembly and Senate have been dissolved. All political parties and associations have been closed ... Great Turkish Nation ... outside of you sacrificial heroes, wait in peace of mind and security for further information to be provided to you from time to time from the Armed Forces which are fully at your command and in your service.

In the name of the Turkish Armed Forces Intervention Central Headquarters, Talat Aydemir. ${ }^{31}$

Ultimately, the drama ended unsuccessfully for Aydemir, as Lieutenant Colonel Ali Elverdi, listening to the broadcast at home, had the presence of mind to jump into his jeep and head directly to the radio station. According to Hale: "Singlehandedly, he entered the radio station $^{32}$ and broadcast several announcements telling the listeners to ignore Aydemir's earlier proclamation and assuring them that the government was still in control." ${ }^{, 3}$ After Elverdi managed to repeal the message 
Aydemir's forces were able to recover their composure, take the Lieutenant Colonel captive, and reinstate the previous message, but for all practical purposes, the damage was done. In the end, the General Staff cut the lines from Etimesgut, a suburb of Ankara, and rebroadcast a message that all was once again under control of the government, and this final assurance would suffer no contestation. ${ }^{34}$ The former colonel was picked up by the police at around noon at the house of a friend. ${ }^{35}$

The event highlights a number of key points. With a centralized media source a message can be broadcast to a large audience that has no other means to challenge the truth of the "reality" being conveyed and so behave according to the message received. Until Elverdi took over the station, the vast majority of listeners were under the impression that the coup had already occurred. Reflecting on the events above, former Prime Minister Bülent Ecevit, who at the time was Minister of Employment, remembers telling his wife to pack a suitcase with clothes, food, and a few philosophical books in anticipation of the soldiers he assumed would be coming for him. ${ }^{36}$ Such effective control over information and interpretations by the receiving audience could not be attained in a commercial media context, giving its holders powerful control over public behavior when necessary.

The message itself also demonstrates that the idea of society as an actor in intervention had not entered Aydemir's mind. In the message, he was using an initiation code "sacrificial heroes" (halaskâr fedailer) to try to rouse other military elements to his cause. His primary understanding of the power of the radio shows an interpretation of the media as a walkie-talkie; his concern was not with mobilizing the public. ${ }^{37}$ To the extent that he was addressing the public his intent was to keep them on the sidelines and to remain in their homes and wait for further information. According to the text of the announcement provided by Birand et al, the message even included the warning that those who would try to go out on the street would be shot. ${ }^{38}$ With complete and effective control over the lines of communication, there was no need to mobilize a public that might even take positions against him; thus, it was better that they stay on the sidelines.

Even during the 1980 coup, a central, monolithic "reality" was able to be maintained, but this time over both television and radio. Most Turkish citizens living at the time have identical shared images of Chief of the General Staff (who later became the president) Kenan Evren providing perspective to the general public. ${ }^{39}$ For events after the commercialization of television in the early 1990s, on the other hand, the public, though sharing the memory of the same event, would have a different image in their mind transmitted from a potentially wide variety of perspectives. Ultimately, as the number of stations multiplied, any direct broadcasting would reach smaller numbers of people. Control of information within one station is relatively easy; the control of information and, perhaps more importantly, its accompanying interpretations, across numerous stations would require increasingly draconian measures. Direct communication with the people was suddenly fractured in the early 1990s and, from then on, in every instance where the military desired such communication, they had the reality of simultaneously competing with other voices and sources of information. 
An additional factor influencing the behavior of the military after the advent of commercial television is that it created an environment where much less could be hidden from view, enhancing public oversight. During the period of state-run media, it was much easier to regulate and control information from "behind the curtain." In a centralized state-controlled context, if actions were taken to restrict, constrain, or punish the media outlet, there was no one else to report that it occurred. With ubiquitous media, the act of restricting or punishing sources suddenly was forced out into the open and observed. Even when those other channels observing the relation of another media source or channel could not openly criticize the actions they could at least observe and inform the public that actions were being taken.

This new dilemma has been observed by a number of scholars. Toprak claims that "[f]ollowing these improvements in communication channels, it was increasingly difficult for governments to hide information from the public or to censure it." 40 This consequence would also be true for the military at times when they desired to appropriate the means of communication with the public, heralding a change from the past. For example, prior to commercialized media in the 1980 s, the public paid little attention to what was occurring in the southeast "because of strict media and information manipulation by the armed forces at the time." 41 Contrast this with Cizre and Çınar's claim that the military's response to inquisitive external parties in regard to actions in the southeast has moved from outright denial of actions in the 1980s to "argumentative rationality" for their operations, starting in the 1990s. ${ }^{42}$ Undoubtedly, the omnipresent media has a strong hand in decreasing the possibility of denial, forcing a search for justification. Legitimacy in the eyes of the public could no longer be achieved simply by controlling information, which increasingly approached impossibility; commercialized media changed society's understanding and awareness of itself, necessitating a new approach, the solution to which was also provided by the agent of change itself.

\section{Citizen-Consumer and Need for Consent}

The changes that took place when commercialized media entered society did not only alter the logistics of communication and information dissemination; they were an effective catalyst for the "consumerization" of Turkish society. Consumerism in society exploded with the movement toward the market economy during the Turgut Özal years in the 1980s, but private television and the selection it brought was arguably the tool that most profoundly led to its internalization by the masses. Consumption and choice suddenly entered the intimate domain of the home and allowed the citizen in convenient and private fashion to choose and consume on a perpetual basis. This provided a feeling of ownership and choice that was increasingly unhindered as the options multiplied. Toprak's account of the public reaction to the initial blocking of private stations by the government in which millions of people "took to the streets" and demanded "their television and radio channels back" is illustrative in this regard. ${ }^{43}$ The public, accustomed to the power of choice, became mobilized 
when their "rights" as consumer were challenged, and they demonstrated the understanding that the channels and choices were "theirs."

For those seeking to guide society and establish or maintain their worldview, the increasing awareness of citizens as consumers changed the rules of the game and created the need to compete in order to acquire consent. Toprak recounts a television comedy sketch introduced after the introduction of private television in which a general announces he is taking over the government only to find out that other generals are simultaneously declaring coups from other channels. ${ }^{44}$ This cleverly points out the new dilemma for those who want to exert control over society; suddenly, they are constantly struggling with others with competing visions for society, leaving the "consumers" of those visions to decide. Legitimacy comes from gathering consent for one's desired views and actions, and consent is obtained through mastering the tools of the new social power, the media. Nuran Yildiz, reflecting on Gramsci, writes:

In the modern state, the source of obedience, submission, and acceptance comes not from the creation of fear produced by violence and force, but through consent that comes from persuasion. And this consent is produced through oral, visual, and written means. ${ }^{45}$

Thus, the arena of contestation opened up by commercial media also becomes the primary mode through which one attains "consent" of the people, who are increasingly understood as consumers with choices.

Other elements of society that desired to gather public consent quickly recognized the opportunity created by the advent of private television. One of the key "winners" of consent within the new environment was the RP and the emergence of a modern religious discourse. As Öncü points out, the introduction of private channels enabled the RP to recreate themselves in the eyes of the public through a stereotype-breaking media campaign in 1991, presenting themselves as a party that was modern, concerned about the issues of the day, and one that could address the needs of all segments of society. ${ }^{46}$ During the period of state-controlled media, religion was not given space to construct itself in these ways; on the contrary, it was basically marginalized, sterilized, and left as a private and peripheral element of society; ${ }^{47}$ therefore, they presented a new and significant challenge to military and state elites.

There is fairly strong evidence that this induction of religion as a possible choice among the new options available with private television paid dividends for the Welfare Party. The RP suddenly became successful in the big cities in the 1990s. In the 1994 local elections, they won the mayoral seats in the two largest cities in the country (Istanbul with 25 percent and Ankara with 21 percent of the vote). ${ }^{48}$ The fact that in the 1990s the RP's vote both continually increased, and increased in demographic areas that had previously garnered low percentages of support, should cause one to search for an explanation. Their popularity among the migrant urban poor in itself could not explain the change in this context, as the effects of urbanization had begun as far back as the 1950 s. ${ }^{49}$ A more likely 
explanation is found in the proliferation and privatization of the media during this time. The RP's (and its predecessors') historical support, which had been grounded in the rural population (where the influence of media was slower to develop), suddenly increased greatly in the urban areas where access to the media was much more readily available.

The gains made by the RP in the 1990s led the military to enter the realm of the media in a similar fashion to counteract the success of the Islamists. Tanel Demirel points out: "The Turkish army especially after the late 1980s intensified its public relations exercises to enhance its image." ${ }^{50}$ He goes on to cite examples of this such as inviting journalists to military schools and facilities and informing journalists of the military's involvements in community-service activities. ${ }^{51}$ Cizre also notes: "The military has been very successful in establishing a new relationship with targeted groups in society." 52 When the military finally decided to intervene against the RP on February 28, 1997, their interaction with society demonstrated the existence of new realities, leading them to approach the public as consumers from whom consent was necessary for action.

Prior to, during, and following the intervention process the military exploited the power of the media to gain consent and to mobilize the consumers to take ownership of their shared worldview. This phenomenon was observed by numerous scholars. To provide just a few examples, Quinn Mecham notes: "For several months the military continued to issue threats against the government, mobilizing civil society and the media in an anti-Islamic drive. ${ }^{, 53}$ Heper also tells us that the TAF "put pressure on the government by giving several briefings to the members of such state and semi-state agencies as the judiciary and universities as well as to the mass media and the business circles." 54 Furthermore, and perhaps most revealing, Cizre and Çınar argue that the military intended to create its own channels of support "by acting like a political party directly addressing the public." 55 The authors go on to explain why this shift has occurred:

A major element of rupture with the past is the way the military's priority has shifted from invoking societal indifference and fear to producing consent and support. In trying to undermine the RP's popular appeal ... it has appealed directly to the organized groups of the modernized urban-secular sectors- the business world, media, academia, public prosecutors, judges, leaders of civil societal associations - and even held briefing meetings with them to warn them of the extent and magnitude of the Islamic threat. ${ }^{56}$

The military was prompted to action in response to the popular appeal garnered by the RP, which itself came through the expansion and privatization of the media. Addressing the Islamic threat led to a change of behavior, from "invoking societal indifference and fear to producing consent and support." ${ }^{, 57}$ This demonstrates a new significance to the role of the public; instead of being left on the sidelines, they ultimately were encouraged to enter the "arena of contestation," legitimizing the military's actions and assisting in the generating of consent. 
As the military's approach toward the public during the course of interventions changed, it also blurred the fine lines that previously existed between civil mobilization and the mobilization of the Armed Forces. Shortly after the 1997 process, Nilüfer Narlı points out that "military officers in uniform held hands with civilians in Ankara, Istanbul, and Izmir on October 25, 1998, symbolically manifesting the removal of civil/military boundaries." 58 Not only during the intervention but also after, the military worked to "market" itself through events that put citizens in the role of consumers. This is also well-documented by Esra Özyürek, who argues that the state elites and military approached the celebrations surrounding the seventyfifth anniversary of the Republic in 1998 in a completely new fashion, establishing society as consumers who should ultimately "take ownership of the Republic" and whose enthusiasm would legitimize the intervention the year before. ${ }^{59}$

These events demonstrate a change in the structural interaction between the Armed Forces and society, changes that took place in a short amount of time and need to be explained. The general public's entrance into the "arena of intervention" shows that the military no longer chose to approach them with the "old methods" even during times of crisis. As this change has widely been observed to have taken place during the period exactly coinciding with the rapid development of commercialized media it seems logical to search there. Commercial media is not the only or first product of consumerism in Turkey, but it was arguably the strongest catalyst in the creation of citizen consumers. It was this change within society that forced an alteration in the military's approach, leading them to "market" themselves and their worldview to generate consent and to mobilize the public. Although they extensively used the media during the intervention, this is not the primary evidence, as they had used the media in all the proceeding interventions. Rather, it is how they used it, the manner in which they presented themselves and their agenda to the public that changed and conformed to a society that had internalized the "consumer" worldview.

\section{The Events Surrounding the Ergenekon Indictments}

As time has passed from the February 28 process and its immediate aftermath, the evidence has strongly pointed in favor of the assessment that the pattern of interaction observed in the 1997 intervention, argued to be connected to the developments brought by commercial media, was not isolated to a specific context but continues to the present. Although the process began earlier in the year, on July 1, 2008, a shockwave passed over Turkish society as a retired force commander of the gendarmerie and two retired commanders of army divisions were taken into custody along with 18 others, including businessmen and journalists, ${ }^{60}$ and questioned in regard to what has come to be known as the Ergenekon indictments. ${ }^{61}$ Much of the shock derived from the fact that civilian authorities were actively pursuing cases against high-level retired officers, who were taken into custody by police entering military quarters, whose houses were thoroughly searched, and who would be tried in civilian courts and because the military command, after urging all elements of society (including 
the press) to maintain restraint and common sense, chose largely to remain silent. The premise behind the indictment is that junior active elements (and former elements) of the Armed Forces formed a group (çete) with elements from civil society to depose the ruling AKP by creating an environment that would lead to wide social support and consent for an intervention. The claims, stemming from supposed leaked documents, argue that the group planned to create chaos by assassinating journalists and intellectuals and by mobilizing civil society to protest the government, thus creating legitimacy for an intervention. ${ }^{62}$ Connections to this case were also made with events that came out of an alleged diary of the retired Admiral of the Naval forces, Özden Örnek, accessed by a weekly magazine, Nokta, in 2006 that describes two attempted interventions in 2003 and 2004 before generals taken into custody, like Şener Eruygur, entered retirement. ${ }^{63}$ Although consistently denying the authenticity of the diary, former Admiral Örnek has subsequently dropped his case against the editor of Nokta. ${ }^{64}$ Though one might never know with certainty exactly what transpired, other documents have been recovered from other suspects that seem to confirm the broad outline of the diary's account. ${ }^{65}$

Although the events sent waves of concern through many segments of society, the unique developments led the editor-in-chief of the daily Radikal, İsmet Berkan, to claim: "Whatever may come from the Ergenekon court cases, the investigation itself has even raised the current democratic standards. We have experienced another silent revolution." 66 With the passage of time, however, some of the enthusiasm engendered by the occasion of civilian authorities holding military personnel accountable for unlawful behavior has waned. As the indictments continue to mount (as of spring 2010), some of which have dubious credibility and appear politically motivated, and the Constitutional Court of Turkey has annulled a law that would allow military personnel to be tried in civilian courts, previously existing optimism regarding the developments of the cases has notably plunged.

As the indictments are ongoing and a lot of the information has been kept under wraps, it would be foolhardy to firmly claim veracity of certain accusations, especially in regard to the more recent events. However, as time passes, there seems to be increasing evidence to support the earlier intended interventions corresponding to the diaries attributed to former Admiral Örnek. ${ }^{67}$ In addressing the indictments, this article largely draws conclusions from the general structure and pattern of assumptions that have been established in regard to the "events." The assumptions themselves, whether grounded in substance or not, show a change in the general mentality of what attempting an intervention in today's context would entail; the pattern of interaction (even by would-be plotters) seems to conform to the new realities opened up by the existence of citizens as consumers.

Distinct from the assumptions made by Aydemir and other plotters in the 1960s, those with a mind to intervene (whether by coup or by softer means such as exhibited in 1997) assume the need to mobilize support from the media and civil society. Whereas Talat Aydemir, for example, intended to keep the public out of the plotting, all accounts of the more recent alleged attempted interventions assume as foundational that gathering support from civil groups is square one. The indictments, for 
example, include not only current and former members of the military but also civic and business leaders and members of the press. ${ }^{68}$ There is an understanding that the military would need to work in tandem with society to meet their aim-drastically different from the earlier interventions. As for the attempts that were to have taken place in 2004, which were supposedly more relegated to the military and within the hierarchy of command, Walter Posch notes that "the generals met with several business leaders from the media, among them Aydın Doğan, head of the Doğan group, Turkey's biggest media empire." ${ }^{69}$ This would presumably be in order to mobilize support and consent for potential actions. According to the notorious dairy from the period, the force commanders discussed a plan that included winning over the press, and then encouraging university rectors to "pour their students out into the streets." 70

Furthermore, one of the generals taken into custody who has become a primary suspect, Şener Eruygur, immediately upon retirement from the military became the president of a civil society organization, the Society for Atatürkist Thought (Atatürkçü Düşünce Derneği, ADD) and mobilized mass demonstrations in defense of secularism and to prevent the AKP from occupying the seat of the president. ${ }^{71}$ These are the behaviors of actors engaged in a competitive environment where people are able to make choices and, through ubiquitous and privately-controlled media, decide for themselves what to accept. Although the group intended to operate in secrecy, it no longer could do so merely within the confines of the barracks but had to make linkages to civil society and the non-political elite. Such actions strongly confirm the pattern of behavior that has arisen in the context of crisis and consideration of intervention witnessed in 1997.

\section{Conclusion}

What does this change in civil-military-media interaction portend for the future? Has the "blurring of the lines" been a positive or negative development? A number of scholars have viewed the military's increased utilization of the media outside the intervention context with a critical eye. For example, Michaud-Emin refers to the Armed Forces" "arsenal of unofficial influence" that enables it to retain societal power despite recent developments and legislation that have curbed their official channels of power. High on her list of such unofficial means, she places "public pronouncements," "media briefings," and "public ceremonies.,"72 Cizre also argues that within this new context the military is retaining its power, utilizing the media to "make oral statements," "write written declarations," and "reiterate their positions," maintaining effective control and support through the utilization of security threats and a national security discourse. ${ }^{73}$ In the years closing the first decade of the twenty-first century, the European Union has regularly commented on this behavior by the military. In its most recent progress report for Turkey it writes:

The armed forces have continued to exercise significant political influence via formal and informal mechanisms. Senior members of the armed forces have 
expressed their opinion on domestic and foreign policy issues going beyond their remit, including on Cyprus, the South East, secularism, political parties and other non-military developments. ${ }^{74}$

Generally, there seems to be concern that the military is exerting its force not it conventional ways but by entering into the political sphere as an interested party and by using its high level of public support to put pressure on politicians to listen to its views.

At the same time, however, though the military has often utilized the new conditions effectively to act as a pressure group on day-to-day political activities, this new environment has come with a number of constraints. The ubiquitous nature of commercialized media has created a level of oversight that increases the difficulty and need for legitimization of their behaviors. Commercialized and free media also means that there is an increasing awareness of what is happening outside the country as well as an increased ability to be observed by outside groups, including the EU, the United States, and others. Ever-present media certainly restricts and creates a measure of oversight for any party significant enough to warrant its attention. In a context such as this it would take an extreme situation lending a phenomenal amount of legitimization for the Armed Forces to intervene as they did in the earlier cases.

With today's level of global connectedness through increasing powerful media channels, extreme actions by the military would lead to significant economic and political losses for Turkey and the military as an institution. Gerassimos Karabelias argues: "The independent financial power of the military institution increased at such a pace during the 1990s that it could not afford to retain a stance of being above politics and economics." 75 Perhaps it is true that the military, along with everyone else in Turkey, has a vested interest in the day-to-day politics within the country, but such realities lead to increasingly moderated behaviors, even if those moderated behaviors become more frequent.

If the behaviors of the top brass in recent months are any indication of the days to come, it seems that the military's desire to maintain the trust and support of the masses has been to stay within democratic expectations as much as possible. The decision of the General Staff to allow the civilian courts to do their work and quietly consent to former officers being exposed to investigation appears to be a positive step forward toward further civilian control over the military. This silence by the military has certainly been one that is voluntary and not forced upon them. ${ }^{76}$ Perhaps they are internalizing the perspective of former Chief of Staff Hilmi Özkök, who said in December 2008:

They have accused me of not being like those involved in February 28 and for being silent ... but I acted under the conclusion that all the nation's dynamics and duties to be accomplished should be carried out by those specifically entrusted to carry them out. I completely believed in democracy's virtue and that it was the difficult but most trusted path. ${ }^{77}$ 
The silence of the military as Turkey marches forward in its path toward a more liberal democracy would be a significant development. That there will be further challenges on this path is clear; one such obstacle is the benefit the media organs themselves receive from the sensationalism that comes from the military speaking out through their channels and so have a vested interest in keeping soldiers in politics. ${ }^{78}$ The public also seems content to have its most trusted and praiseworthy institution close by and is genuinely interested in its perspective. ${ }^{79}$ Furthermore, due to the nature of the chain of command, with every new Chief of Staff, the military takes on a slightly different approach and personality. At the same time, however, as Ersel Aydınlı has pointed out, "The Turkish military leadership, both conservative and progressive, now faces the challenge of redesigning its relationship with society under the latter's terms and expectations_-and not their own." ${ }^{\text {" }}$ "This, along with the current developments and the new environment, give reasons for optimism about the future.

\section{Notes}

1. Quoted by Walter Posch, "Crisis in Turkey: Just Another Bump on the Road to Europe?" Occasional Paper No. 67 (2007), p. 11. (Paris: European Union Institute for Security Studies).

2. With the exception, of course, that in 1971, the intervention was through memorandum and the military never completely took the political reins but dictated from the sidelines.

3. Metin Heper, "Turkey: Yesterday, Today and Tomorrow," Southeast European and Black Sea Studies, Vol. 1, No. 3 (2001), p. 14.

4. Nil Satana, "Transformation of the Turkish Military and the Path to Democracy," Armed Forces and Society, Vol. 34, No. 3 (2008), p. 358.

5. Haldun Gülalp, "Political Islam in Turkey: The Rise and Fall of the Refah Party," Muslim World, Vol. 89, No. 1 (1999), p. 40.

6. William Hale, Turkish Politics and the Military (London: Routledge, 1994), p. 174.

7. Linda Michaud-Emin, "The Restructuring of the Military High Command and the Seventh Harmonization Package and its Ramifications for Civil-Military Relations in Turkey," Turkish Studies, Vol. 8, No. 1 (2007), p. 34. For a similar perspective, see also Gerassimos Karabelias, "Dictating the Upper Tide: Civil-Military Relations in the Post-Ozal Decade, 1993-2003," Turkish Studies, Vol. 9, No. 3, pp. 457-473.

8. Hale, Turkish Politics and the Military, p. 174.

9. Udi Lebel, "Civil Society versus Military Sovereignty," Armed Forces and Society, Vol. 34, No.1 (2008), p. 70.

10. Ibid., p. 76.

11. Metin Heper and Tanel Demirel, "The Press and the Consolidation of Democracy in Turkey," in Sylvia Kedourie (ed.), Turkey: Identity, Democracy, Politics (London: Routledge, 1998), p. 109.

12. Ayşe Öncü, "Packaging Islam: Cultural Politics on the Landscape of Turkish Commercial Television," Public Culture, Vol. 8, No. 1 (1995), p. 55.

13. Ibid., p. 55.

14. Ersin Kalaycioğlu, Turkish Dynamics: Bridge across Troubled Lands (New York: Palgrave McMillan, 2005), p. 118-119.

15. Ibid., p. 118.

16. This number had more than doubled since 1980 (3.3 million). Gerard Groc, "Journalists as Champions of Participatory Democracy," in Metin Heper and Ahmet Evin (eds.), Politics in the Third Turkish Republic (Boulder, CO: Westview, 1994), p. 204.

17. Öncü, "Packaging Islam," p. 58. 
18. Ibid., 58. Emphasis added by the original author.

19. Groc, "Journalists as Champions of Participatory Democracy," p. 205.

20. Öncü, "Packaging Islam," p. 55.

21. Ibid., p. 56.

22. See RTÜK website, http://www.rtuk.org.tr/sayfalar/default.aspx.

23. This situation remained until $8^{\text {th }}$ EU Harmonization Package was passed in May 2004. For further information see Ümit Cizre, "Ideology, Context and Interest: The Turkish Military," in Reşat Kasaba (ed.), The Cambridge History of Turkey, Volume 4: Turkey in the Modern World (Cambridge: Cambridge University Press, 2008), p. 322.

24. Binnaz Toprak, "Islam and Democracy in Turkey," Turkish Studies, Vol. 6, No. 2 (2005), p. 174.

25. Öncü, "Packaging Islam," p. 57.

26. Toprak, "Islam and Democracy in Turkey," p. 174. The amendment in the 1982 Constitution that allowed for private television and radio was created in 1993. For further information see Ergun Özbudun, "Democratic Reforms in Turkey, 1993-2004," Turkish Studies, Vol. 8, No. 2 (2007), p. 184.

27. Ergun Özbudun, Contemporary Turkish Politics: Challenges to Democratic Consolidation (Boulder, CO: Lynne Rienner, 2000), pp. 63-64.

28. Cizre, "Ideology, Context and Interest," p. 322.

29. Nuran Yıldız, Tanklar ve Sözcükler [Tanks and Words] (Istanbul: Alfa Yayınları, 2007), p. 261.

30. Satana, "Transformation of the Turkish Military and the Path to Democracy," p. 373.

31. Mehmet Ali Birand, Can Dündar, and Bülent Çaplı, 12 Mart Íhtilalin Pençesinde Demokrasi [Democracy in the Clutches of the March 12 Intervention] (Ankara: İmge Kitabevi Yayınları, 1994), p. 106.

32. Birand et al claim that he was assisted by two privates, and other accounts give even more. See Kurtul Altug, 27 Mayss'tan 12 Mart'a [From May 27 to March 12] (Istanbul: Yilmaz Yayınları, 1991), p. 258.

33. Hale, Turkish Politics and the Military, p. 167.

34. Ibid., p. 168.

35. Ahmad, The Turkish Experiment, p.185; Hale, Turkish Politics and the Military, p. 168.

36. Birand et al, 12 Mart İhtilalin Pençesinde Demokrasi, p. 107.

37. Talat Aydemir, Talat Aydemir'in Hatıraları [The Memoirs of Talat Aydemir] (Istanbul: May Matbaas1, 1968), p. 255.

38. Birand et al, 12 Mart Íhtilalin Pençesinde Demokrasi, p. 106. Most other accounts did not give such detailed information about the announcement, one notable exception being Aydemir's own memoirs. His does not include a sentence threatening the public that they might be shot, but one could also argue that Aydemir would have obvious reasons to leave that out.

39. The films about the 1980 coup that have become popular starting from the twenty-fifth anniversary of the coup often draw upon this phenomenon by showing the familiar footage.

40. Toprak, "Islam and Democracy in Turkey," p. 174.

41. Satana, "Transformation of the Turkish Military and the Path to Democracy," p. 366.

42. Ümit Cizre and Menderes Çınar, "Turkey 2002: Kemalism, Islamism, and Politics in Light of the February 28 Process," The South Atlantic Quarterly, Vol. 102, No. 2/3 (2003), p. 314.

43. Toprak, "Islam and Democracy in Turkey," p. 174.

44. Ibid., p. 175.

45. Yıldız, Tanklar ve Sözcükler, p. 67.

46. Öncü, Packaging Islam,” p. 61.

47. Ibid., p.56.

48. Gülalp, "Political Islam in Turkey," p. 30.

49. Ibid., p. 30.

50. Tanel Demirel, "Soldiers and Civilians: The Dilemma of Turkish Democracy," Middle Eastern Studies, Vol. 40, No. 1 (2004), p. 142.

51. Ibid., pp. 142-143. 
52. Cizre, "Ideology, Context, and Interest," p. 311.

53. R. Quinn Mecham, "From the Ashes of Virtue, a Promise of Light: The Transformation of Political Islam in Turkey," Third World Quarterly, Vol. 25, No. 2 (2004), p. 344.

54. Heper, "Turkey," p. 15.

55. Cizre and Çınar, "Turkey 2002," p. 322.

56. Ibid., p. 322.

57. Cizre and Çınar, "Turkey 2002," p. 322.

58. Nilüfer Narl1, "Civil-Military Relations in Turkey," Turkish Studies, Vol. 1, No. 1 (2000), p. 121.

59. Esra Özyürek, Nostalgia for the Modern: State Secularism and Everyday Politics in Turkey (Durham, NC: Duke University Press, 2006), pp. 134, 138.

60. “Turkey's Gang Probe Widens, More Opponents Detained," Hurriyet, July 1, 2008.

61. Ergenekon is originally the name for a legendary valley where the Gokturks fled to safety and lived in peace until they grew too large for the area. The legend usually includes the Turkish myth of a wolf that leads them into (or sometimes out of) the valley. Ergenekon and the grey wolf (bozkurt) have often been appropriated and used by extreme nationalistic groups. For further information, see “Turkish Epic Myths Live On,” Turkish Daily News, April 5, 2008.

62. "Turkish Prosecutors File Indictment on Controversial Ergenekon Case," Hurriyet, July 14, 2008.

63. Posch, "Crisis in Turkey," p. 19.

64. İhsan Dağı, "The Road to Ergenekon,” Today's Zaman, January, 26, 2009.

65. William Hale and Ergun Özbudun, Islamism, Democracy and Liberalism in Turkey: The Case of the AKP (New York: Routledge, 2010), p. 89.

66. İsmet Berkan, "Bir Temel Tespit," Radikal, July 3, 2008.

67. For example, the comments by the former chief of General Staff point in this direction. See Murat Yetkin, "Özkök'ten 'savunma': Beni 28 Şubat'takiler gibi davranmamakla suçladılar," [A Defense from Özkök: They Accused Me of not Behaving like those Associated with February 28] Radikal, December 25, 2008. For further discussion of the events, see Posch, "Crisis in Turkey," pp. 18-20.

68. "Turkish Prosecutors File Indictment on Controversial Ergenekon Case," Hurriyet, July 14, 2008.

69. Posch, "Crisis in Turkey," p. 19.

70. Hale and Özbudun, Islamism, Democracy and Liberalism in Turkey, p. 89.

71. Ibid., p. 19.

72. Michaud-Emin, "The Restructuring of the Military High Command and the Seventh Harmonization Package and its Ramifications for Civil-Military Relations in Turkey," p. 34.

73. Cizre, "Ideology, Context, and Interest," p. 311.

74. Turkey 2008 Progress Report (Brussels: Commission of the European Communities, 2008), p. 9.

75. Gerassimos Karabelias, "Dictating the Upper Tide," p. 467.

76. For an extended argument on this point, see Michael Wuthrich, "Structural Factors Influencing Military-Media Relations in Turkey," unpublished paper, 2009.

77. Yetkin, Radikal, December 25, 2008.

78. For an extended argument, see Michael Wuthrich, "Factors Influencing Military-Media Relations in Turkey," (2010), unpublished paper.

79. Cizre, "Ideology, Context and Interest: The Turkish Military," p. 317.

80. Ersel Aydınlı, "A Paradigmatic Shift for the Turkish Generals and an End to the Coup Era in Turkey," Middle East Journal, Vol. 63, No. 4 (2009), p. 590. 